\title{
Some Aspects of the Soil Physical Status of the Vine Plantations in the Context of Rural Development
}

\author{
Judit Pető ${ }^{1 *}$, Attila Hüvely ${ }^{1}$, András Palkovics $^{1}$, Viktor Vojnich ${ }^{1}$ \\ ${ }^{1}$ John von Neumann University, Faculty of Horticulture and Rural Development, Kecskemét, Mészöly \\ Gyula str. 1-3. 6000 Hungary
}

Accepted October, 2018

\begin{abstract}
The rural development grants - among others - help to promote the competitiveness of the agricultural activities. Plantations take great interest in the southeastern part of Hungary. Farmers need to make soil tests before plantation of fruit and grape. We investigated the distribution of the main physical characteristics in this area. For the establishment of vineyards, the areas were adequate according to the $\mathrm{pH}$, and salt content. The results of the soil tests show some strong relationships between the determined physical parameters.
\end{abstract}

Key words: oil physical status, plantation, vineyard, soil tests, rural development

\section{Introduction}

In our region, horticultural production is one of the most important classical activities, as it provides livelihood to the population, and contributes significantly to the vegetable and fruit supply of the whole country. Among the EU's agricultural subsidies, vineyards and fruit planting have opened significant resources for farmers in several cycles to promote plantation, modernization, irrigation and breeding. As we have already reported on several occasions, from 2009 we have carried out soil tests, including preinstallation soil tests, in our accredited soil and plant testing laboratory.

During our studies, we carried out surveys regarding the number of new plantations in a year, their size, their territorial distribution and their type as well. We have found that in the period under review, in our region vineyards have been planted in the largest total area.

The most important soil physical properties $(\mathrm{pH}$, salinity, texture, calcium carbonate and humus

* Corresponding author: Judit Pető, peto.judit@kvk.uni-neumann.hu

(cc) BY-NC-ND $\odot 2018$ Judit Peto et al., published by Sciendo. This work was licensed under the Creative Commons Attribution-NonCommercialNoDerivs 3.0 License content) and the chemical properties, the most important macro and micro element content $(\mathrm{N}, \mathrm{P}$, $\mathrm{K}, \mathrm{Ca}, \mathrm{Mg}, \mathrm{Zn}, \mathrm{Cu}, \mathrm{Fe}, \mathrm{Mn}, \mathrm{S}$ ), it is possible to plan the level of nutrient supply before installation and later in culture as well [1]. In case of professionally justified additional tests (phenolphthalein alkalinity, sludge fraction, swapping acidity, base replacement test, and phylloxera immunity test in the case of rootstock grape, physiological calcareous content) are required). The installation permit is issued by the competent authority, on the base of the soil protection plan made by an expert in the case of plant cultures. The concentration of certain soil parameters above or below the limit value poses a risk (e.g. pH, salt, lime, humus).

In our present study, we would like to present the results of the most important physical properties of the soil in the planned vineyards. We followed the frequency of occurrences of their risky values and the correlations among the parameters.

The EU's rural development policy helps the rural areas of the EU to meet the wide range of environmental and economic challenges. As twothirds of the territory of Hungary is considered as a rural area, these programs provide potential opportunities. In recent years, efforts have been made to make the fruit market more competitive in EU. Due to their beneficial physiological effects, 
the promotion of the consumption of fruits and the processing industry play a prominent role. The natural conditions of Hungary are excellent for the production of good quality grape and fruits, and large varieties of fruit containing processed products as well. The southern part of the Great Plain is the largest horticultural area in the country.

In our region, significant resources have also been set for the installation of new plantations. The use of environmentally friendly and innovative growing methods and modernization of irrigation in plantations is granted as well. Furthermore, due to the climate change, the likelihood and frequency of extreme weather conditions, like drought and floods and inland waters are also increasing [2, 3]. Crop quality would be increased by choosing the right varieties, cultivation methods and economical irrigation technologies. Environmental management programs help farmers and soil experts to pre-assess the future development potential and sustainability of the planned plantations, through making preliminary determination of the main physical and chemical properties of the soil as well as the main nutrient contents. Cultivation, based on soil tests, contribute to the improvement of soil structure, nutrient supply, water management and natural biological activity of the soil $[4,5]$. As we reported earlier, the most samples were taken in 2011 for planting, and mainly in Bács-Kiskun County [6]. In this study these samples were processed, and we show the results of planting test examinations. We evaluated the analysis of some of the soil main physical parameters; the values and the main relationships between the most important physical parameters of the examined soil samples.

\section{Material and Methods}

We have processed the samples arrived among 2009 to 2015 to the accredited Soil and Plant Testing Laboratory of the Faculty of Horticulture and Rural Development in the University of John von Neumann and in the predecessor institutions (Pallasz Athéné University and Kecskemét College Faculty of Horticulture). Soil sampling was carried out by registered soil protection experts in contact with our laboratory; and the sampling was made by standard methods (collection of soil profile samples at depths $0-150 \mathrm{~cm}$ and collection of average samples usually from the layers of 0 30 and $30-60 \mathrm{~cm}$ depths respectively, while from the layers of $0-20$ and $20-40 \mathrm{~cm}$ depths in the case of berries). Planned fruit and vineyards were mainly located in the South Great Plain region, mainly in Bács-Kiskun County. The test sample number was very significant for each parameter between 2100 and 2580 for each parameter.
Analytical testing methods were made in the Soil and Plant Testing Laboratory of Faculty. Analysis of all the examined parameters was based on certified methods, detailed in the laboratory certificate. The number of accreditation documents of the Soil and Plant Testing Laboratory was NAT-1-1548 / 2007 / 2011 or $\mathrm{NAH}-1-1548$ / 2015. During the examination period the laboratory continuously performed its accredited activity.

The presentation of our results is limited to the laboratory testing of vineyards.

From the physical characteristics, the $\mathrm{pH}$ was determined by potentiometry and electrical conductivity (EC value) by conductometry using laboratory instruments (Orion Star, HACH Lange). $\mathrm{PH}$ was measured in aqueous and in $1 \mathrm{~mol} / \mathrm{dm} 3$ potassium chloride solution as well. Soil plasticity was estimated on the base of the so called Arany plasticity by volumetric method $[6,7]$. Watersoluble salt content was estimated on the base of electrical conductivity of the soil, filled up with water. The calcium-carbonate content was determined by a calcimeter volumetrically, and humus content was determined by spectrophotometric way after destruction by potassium dichromate/sulphuric acid. The nutrient contents were determined by ICP-OES spectrometry.

Our results were statistically evaluated by SPSS 13.0 for Windows and Microsoft Office Excel programs. Average levels, standard deviation and statistically significant differences were estimated. We determined the occurrence of risk values, and Pearson correlation analysis [6] was used to reveal the correlations between the examined parameters. Essential relationships were determined at $5 \%, 1 \%$ and $0.1 \%$ significance level.

\section{Results and Discussions}

Soil samples were processed continuously upon arrival, throughout the investigation period. The presentation of our results is limited to the laboratory testing of vineyards. The average $\mathrm{pH}$ of the samples was in the slightly alkaline range (Figure 1). PH values did not show significant variance. The difference between the $\mathrm{pH}$ measured in aqueous and $1 \mathrm{~mol} / \mathrm{dm} 3$ potassium chloride solution soil suspension was not significant, about 0.29 on average. It suggests that the hidden acidity of the soil of the areas affected by vineyards was small. Standard deviation of the $\mathrm{pH}(\mathrm{KCl})$ was higher than that of the aqueous $\mathrm{pH}$.

A simple and fast method for characterizing the physical characteristic of the soil is the determination of the so called Arany plasticity 
number. This method was characterized by a Hungarian soil scientist and well characterizes the soil texture and softness. On the basis of our results, a significant part of the soils seemed to be sand, representing $75.4 \%$ of the samples (KA 2530 ). Sandy loam soil was $23.2 \%$ of the samples (KA 31-37), the ratio of the more loam, loamy clay and clay type samples did not reach $5 \%$. The distribution of the soil plasicity is shown in detail in Figure 2.

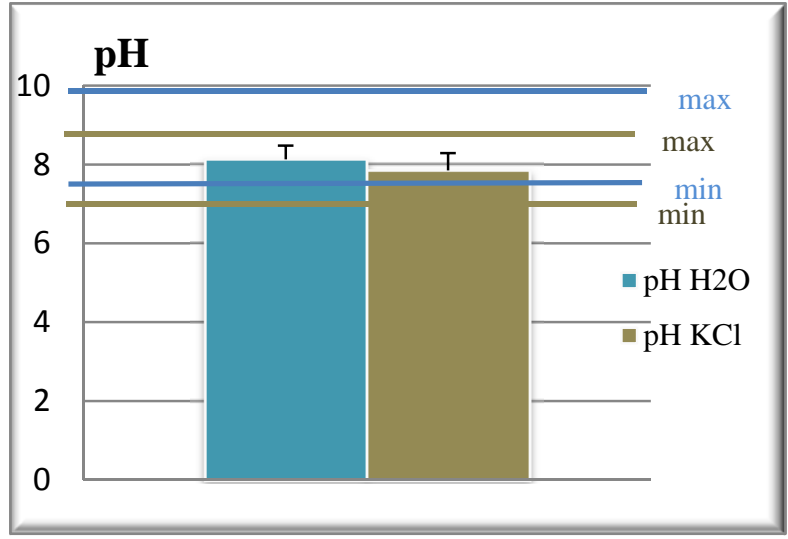

Fig. 1. Average values, standard deviation and indication of the lowest and the highest values of $\mathrm{pH}$ in the soil samples

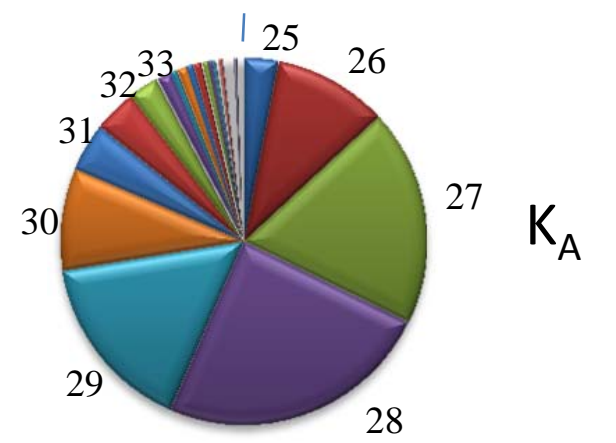

Fig. 2. Distribution of the plasticity of the soil samples estimated by Arany plasticity number on the base of the frequency of the occurrence

Water-soluble total salt content was low in usual. About three quarters $(72.7 \%)$ of the samples did not reach $0.02 \mathrm{~m} / \mathrm{m} \%$ soluble salt content. This result reflects the low salt content of the sandy soils of the inter Danube-Tisza region, which in many cases is coupled with a poor supply of nutrients. However, since the grape is not a nutrient-demanding plant, it is well grown on these soils. Furthermore a significant part of the vineyards is located in this region of the country $[6,7]$.

The relationship between the individual physical parameters was examined in detail. The $\mathrm{pH}$ of water and $\mathrm{KCl}$ showed a very strong relationship ( $r=0.84, p<0.001,0.1 \%$ level). Regarding the other parameters, obviously as a result of the large sample size, we got very strong correlations. Both aqueous and $\mathrm{KCl} \mathrm{pH}$ were in negative correlation with Arany plasticity and water-soluble salt content, at a level of significance of $0.1 \%$, (in all cases reaching a level of significance of $0.1 \%$ ). The results show that increased acidification of our soil can increase the soluble salt content and saline content and vice versa [8].

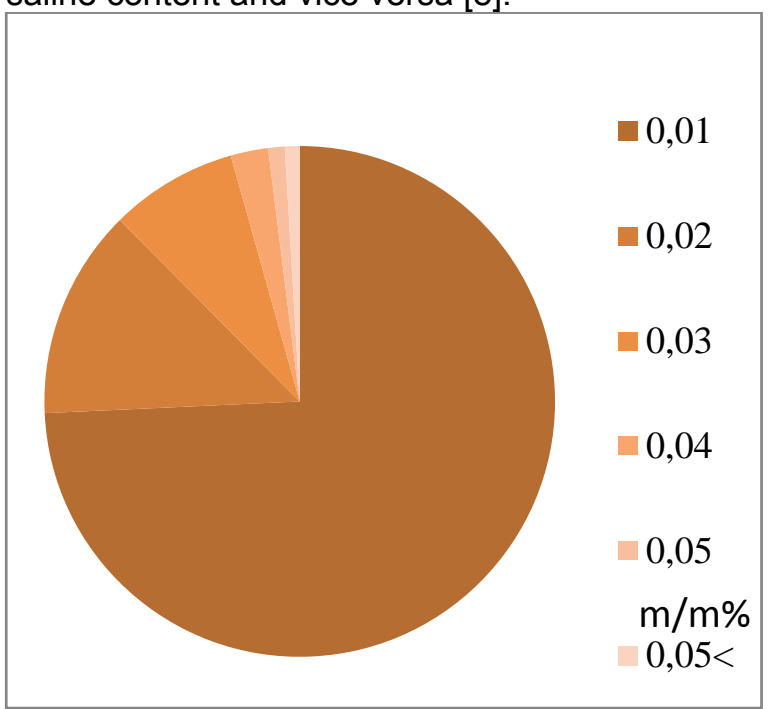

Fig. 3. Water-soluble salt content of the soil samples presented in frequency basis

According to the 90/2008 Decree of the Ministry of Agriculture detailed regulation of the preinstallation soil protection plan exists, the occurrence of the hazardous test parameters was also investigated in our study. Regarding aqueous $\mathrm{pH}, 1.76 \%$ of the samples showed a risk of high $\mathrm{pH}$ (> 8.80), whereas low pH did not occurred in our samples (Table 1).

Table 1.

Risk limits for test parameters and percentage occurrence of the hazardous values

\begin{tabular}{||c|c|c||c||}
\hline Test type & Unit & Risk limit & $\begin{array}{c}\text { Frequency of } \\
\text { prevalence \% }\end{array}$ \\
\hline \hline $\mathbf{p H}\left(\mathrm{H}_{\mathbf{2}} \mathbf{O}\right)$ & - & $>8.80$ & 1.72 \\
\hline $\mathbf{p H}\left(\mathbf{H}_{\mathbf{2}} \mathbf{O}\right)$ & - & $<5.50$ & 0.00 \\
\hline $\begin{array}{c}\text { Water } \\
\text { soluble salt } \\
\text { content }\end{array}$ & $\mathrm{m} / \mathrm{m} \%$ & $>0.15$ & 0.00 \\
\hline
\end{tabular}

The water-soluble salt content in our samples was far below the risk limit, so there was no risk of 
installation in regarding this parameter. Extremely high $\mathrm{pH}(\mathrm{H} 2 \mathrm{O})$ level appeared in barely $2 \%$ of the soils.

\section{Conclusions}

A significant part of the plantations was the planting of grapes during the period under examination, which is a traditionally cultivated horticultural sector in the southern part of the Danube-Tisza Interfluve. Between 2009 and 2013, grape planting accounted for $83.6 \%$ of plantations [9]. This paper presents a general description of the soils of plantations to be planted. The value of our work is that processing and reporting of such studies which have not taken place in this region nowadays. Our work processed more than 2000 soil samples. In this study, we performed the partial physical characterization of the samples studied in the period 2009-2015.

The normal renewal of the old vineyards is necessary and creating new plantations is also granted as a part of rural development and agricultural in our region. The technological development, modernization and the sustainable development of rural economy in this territory is may also be granted. In the Danube-Tisza Interfluve, physical quality and chemical composition of the soils and the underlying rocks have a wide variety. Making soil physical tests and the required analysis of the test results help the farmers work efficiently and contribute to the realization of economical and environmentally friendly activities.

Laboratory soil tests of the planned plantations showed moderately alkaline $\mathrm{pH}$ and low soluble salt content. The risk of planting is not caused by the above parameters.

Soil $\mathrm{pH}$ showed a very close negative relationship with salinity and plasticity.

We evaluated the analysis of some of the soil main physical parameters; detailed results of other physical and chemical soil tests will be shown in other papers. We are on continuing the studies and providing a more detailed and comprehensive analysis of the data in our accredited Soil and Plant Testing Laboratory. Subsequent studies are suggested to make further subgroups of soil samples regarding areas, sampling types and depths.

By our study we emphasize that the quality of soil should be controlled before planting, and regularly monitored at least every five years thereafter. In this way we can get information on the nutrient kit that can be achieved for plants [10]. It is of particular importance to carry out tests on sandy soils, where the nutrient kit may change rapidly. Nutrients can easily be washed out of the roots zone on sandy soils with precipitation and irrigation. The use of waters from different origin is also essential in the cultivation. The use of inadequate quality sprinkling water sources and the pollution of water should be avoided [11]. As we have shown in several studies, the assessment of the quality of irrigation water is indispensable for modern gardening and agricultural production $[3,12]$. Compliance with these viewpoints will help the sustainable development of the rural economy.

\section{Acknowledgements}

This research is supported by EFOP-3.6.1-162016-00006 "The development and enhancement of the research potential" project. The Project is supported by the Hungarian Government and cofinanced by the European Social Fund.

\section{References}

1. Baglyas, F. (2003). A szőlőskert tervezése (2), - és borszőlőfajták kiválasztása és telepítése. Szép Kertek: Díszkertek Biológiai Kertek Haszonkertek, 6 (26), 4849.

2. Mezősi, G., Bata, T., Meyer, B.C., Blanka, V., \& Ladányi, ZS. (2014). Climate change impacts on environmental hazards on the Great Hungarian Plain, Carpathian Basin. International Journal of Disaster Risk Science, 5 (2), 136-146.

3. Pető, J., Hüvely, A., Vojnich, V., \& Hoyk, E. (2016). Main characteristic composition of some ground and artesian waters in the south between Danube-Tisza Region of Hungary. Lucrari Stiintifice Management Agricol, 18 (2), 93-98.

4. Bardgett, R. (2005). The biology of soil: a community and ecosystem approach. Oxford University Press, 245. 5. Foissner, W. (1992). Comparative studies on the soil life in ecofarmed and conventionally farmed fields and grasslands of Austria. Biotic Diversity in Agroecosystems, Elsevier Ltd., 207-218.

6. Szűcs, I. (2002). Alkalmazott statisztika. Agroinform Kiadó, Budapest, 251-260.

7. Stefanovits, P., Filep, Gy., \& Füleky, Gy. (2010). Talajtan. Mezőgazda Kiadó, Budapest, 470.

8. Szőke L. (2014). Tápanyag gazdálkodás tapasztalatai az ECOWIN projektben 2010 - 2013. (AtHu L 00083/01 sz. projekt. Gradus, 1 (1) 314-321.

9. Pető, J., Hüvely, A., \& Cserni, I. (2014). Plantation programs and their observations in the South-eastern Hungarian region. Proceedings of TEAM 2014 6th International Scientific and Expert Conference of the International TEAM Society, 6 (1), 78-80.

10.Kádár, I. (2011). Review. A műtrágyázási szaktanácsadás alapelve és módszere. Növénytermelés, 60 (2), 137-155.

11. Somlyódy, L., \& Simonffy, Z. (2004): Water in Hungary: with Tradition and Unique Problems to the EU. Begegnungen, Schriftenreihe des Europa Institutes Budapest, Band 25, 127-145.

12. Cserni, I. (2012). Talajaink vízgazdálkodása, növénykultúrák öntözése a Duna-Tisza közén. AGTEDU 2012: A Magyar Tudomány Ünnepe 13. Tudományos Konferencia Kecskemét, 11-19. 